\title{
USE OF RESTORATION PLANTINGS TO ENHANCE BIRD SEED DISPERSAL AT THE ROADSIDE: FAILURES AND PROSPECTS
}

\author{
Rocío de TORRE ${ }^{a}$, María Dolores JIMÉNEZ ${ }^{\mathrm{a}}$, Álvaro RAMÍREZ ${ }^{\mathrm{b}}$, Ignacio MOLA \\ Miguel A. CASADO ${ }^{a}$, Luis BALAGUER ${ }^{d}$ \\ ${ }^{a}$ Department of Ecology, Complutense University, Madrid 28040, Spain \\ ${ }^{b}$ Department of Zoology and Physical Anthropology, Complutense University, Madrid 28040, Spain \\ ${ }^{c}$ Research, Development and Innovation (R\&D) Service, Obrascón Huarte Lain, S.A. (OHL), \\ Madrid 28046, Spain \\ ${ }^{d}$ Department of Plant Biology I, Complutense University, Madrid 28040, Spain
}

Submitted 9 Nov. 2014; accepted 30 Jul. 2015

\begin{abstract}
Plantings are commonly used in roadside reclamation for ornamental purposes and for increasing slope stability and road safety. However, the role of these plantings in restoring ecological processes, such as seed dispersal, has received little attention. We carried out a study to assess the potential role of plantings on roadside embankments to attract frugivorous birds and to enhance seed dispersal mediated by birds from the surrounding landscape. We examined: (1) bird species richness and abundance; (2) patterns of avian spatial distribution within embankments and (3) seed dispersal mediated by birds. Bird richness and abundance did not differ between embankments with and without plantings. However, birds were not distributed randomly within embankments, with levels of species richness and abundance for facultative frugivorous between 4.8-8 times higher in areas closer to plantings. An analysis of bird droppings showed that birds only dispersed seeds of the planted species since no seeds of woody plants from matrices were detected. These results suggest that plantings acted as selective bird attractors, providing food and perches for frugivorous species. Nevertheless, the scarcity of seed-dispersing birds in the surrounding agricultural landscape prevented plantings from enhancing seed dispersal and connectivity to adjacent habitat.
\end{abstract}

Keywords: ecological connectivity, ecological memory, landscape structure, mobile links, ornamental plantings, landfills.

\section{Introduction}

Roadsides are a common scenario all over the world, in which earthwork grading and road operations largely transform the geomorphologic, hydrologic, edaphic, atmospheric, and biotic local conditions (Mola et al. 2011). In ecological terms, this environmental damage translates into a loss of the ecosystem storage pools of water, organic matter, soil banks, and biomass, among other impacts (i.e. reserves sensu Ludwig et al. 1997). Such environmental loss compromises ecosystem recovery and restoration, since these reserves are key components of the local 'ecological memory' (Bengtsson et al. 2003). As a consequence, vegetation re-establishment in roadsides does not usually rely on germination of a remnant soil seed bank, but on two other main sources: (1) Natural immigration of propagules from the surrounding matrix
(Bochet et al. 2007; de la Riva et al. 2011), and (2) Introduction of plant species by humans through revegetation practices such as hydroseeding or planting. The former leads to an over-representation of wind-dispersed plant species on roadslopes and those lacking specific traits for seed dispersal (Bochet et al. 2007), while the latter only includes a few cultivated species.

Disentangling the role of revegetation practices in activating ecological processes is critical for restoring ecosystems damaged by road construction (Coffin 2007).

Plantings along roadsides are usually designed for ornamental purposes, and for increasing road safety and slope stability. However, plantings might also have important effects on ecological processes, for example, by activating seed dispersal by birds and therefore enhancing the connectivity of the roadsides with its surrounding landscape.

Corresponding author: Rocío de Torre

E-mail: rtorrece@ucm.es 
While the relevance of such processes is not well known, the potential of birds in helping to promote vegetation recovery has been shown in other types of degraded lands (Bonet 2004; Méndez et al. 2008).

Bird dispersal is considered a major driver of plant community dynamics over time (Howe, Miriti 2004). Specifically, frugivorous birds constitute the most effective mobile links for connecting habitats, acting as dispersers of seeds of fleshy fruit plants (Howe, Smallwood 1982; Sekercioglu 2006). In fact, these mobile organisms can provide connectivity between isolated areas in fragmented environments (Wilkinson 1997; Nathan et al. 2008). Roadslopes usually lack an internal memory, and birds are considered to be the main mobile links providing an external ecological memory, acting as vectors for seeds and propagules from the matrix (García et al. 2010). Thus, inclusion of plants that provide seeds for birds in the design of roadside restoration strategies may favour the integration of the damaged ecosystem with its surrounding matrix through flows and exchanges. These strategies would alleviate the deficit in bird-dispersed species in roadsides. Previous studies have shown that road infrastructures may create corridors connecting habitat patches (Meunier et al. 1999; Huijser, Clevenger 2006; Reijnen, Foppen 2006, Kociolek et al. 2011) and may provide scavenger bird species with new food sources (Lambertucci et al. 2009). However, it is not known whether this is the case in other guilds or trophic groups.

The main objective of this study is to test whether the standard revegetation practices on roadsides designed for ornamental, safety and slope stability purposes, may activate ecological processes such as seed dispersal. Thus, two ornamental plant species commonly used in roadside revegetation were selected to assess the effect of current planting practices on seed-dispersal by birds in humanaltered landscapes. We examined plantings on roadsides of a new-constructed motorway section to address the following questions: (1) Do plantings on roadslopes act as "attractors" for frugivorous birds? We hypothesized that plantings provide food, shelter, perches, roosting or nesting sites for birds, as observed in other ecosystems (Holl et al. 2000; Wydhayagarn et al. 2009), and (2) Is there an active process of seed dispersal mediated by birds on roadslopes? Our hypothesis was that plantings enhance birddispersed seed arrival from the surrounding matrices to embankments.

Our ultimate aim is to stimulate reflections on effective strategies to foster bird-mediated connectivity between the roadslope and its surrounding matrix, with positive effects on seed arrival, as reported in other settings (e.g., Zamora et al. 2010), to enhance restoration efforts at the roadside.

\section{Material and methods}

\subsection{Study area}

The study was conducted on embankments along the A1 highway, in El Molar (Madrid, central Spain; $40^{\circ} 44^{\prime} \mathrm{N}$, $3^{\circ} 35^{\prime} \mathrm{W}, 800 \mathrm{~m}$ asl), which was opened to traffic in June 2009. The regional climate is continental Mediterranean, characterized by cold winters and dry hot summers.

Average annual rainfall is less than $500 \mathrm{~mm}$. Agriculture and livestock farming have generated a highly deforested surrounding landscape, dominated by cereal crops, xerophytic grasslands and scrublands. The dominant woody species are Cytisus scoparius (L.) Link., Thymus zygis Loefl. ex L. and Rubus ulmifolius Schott. Small woodland remnants consisting of Quercus ilex subsp. ballota (Desf.) Samp., Fraxinus angustifolia Vahl, Juniperus oxycedrus subsp. badia (H.Gay) Debeaux and Pinus pinea L. are also sparsely scattered across the surrounding landscape.

\subsection{Experimental design}

Six different embankments (roadslopes constructed by compacting successive layers of earth) located along $5 \mathrm{~km}$ of the A1 Highway were selected. We chose top-soiled embankments because of their favourable conditions for vegetation establishment (Tormo et al. 2007), but also because bird traffic kills are less likely to occur on raised sections of road than on flat verges or buried roadcuts (Clevenger et al. 2003). Three embankments remained untreated as controls ( $\mathrm{C} 1, \mathrm{C} 2$, and C3). On the other three embankments (P1, P2, and P3), we located experimental plots of $2.25 \mathrm{~m}^{2}$ with clump plantings of fleshy-fruited woody species (hereafter "planted islands") every $45 \mathrm{~m}$ (Fig. 1). The total number of planted islands of woody species was 8, distributed among roadslopes depending on the embankment area, according to a stratified sampling scheme (Table 1).

The planted island layout consisted of one individual of the deciduous tree Prunus cerasifera Ehrh. var. pissardii

Table 1. Characteristics of the six embankments used in this study

\begin{tabular}{lcccc}
\hline $\begin{array}{c}\text { Embank- } \\
\text { ment }\end{array}$ & $\begin{array}{c}\mathrm{N}^{\circ} \text { planted } \\
\text { islands }\end{array}$ & $\begin{array}{c}\text { Surface } \\
\left(\mathrm{m}^{2}\right)\end{array}$ & $\begin{array}{c}\text { Width } \\
(\mathrm{m})\end{array}$ & $\begin{array}{c}\text { Maximum } \\
\text { height }(\mathrm{m})\end{array}$ \\
\hline P1 & 3 & 4400 & 220 & 20 \\
P2 & 2 & 1600 & 160 & 10 \\
P3 & 3 & 4800 & 160 & 38 \\
C1 & - & 1920 & 120 & 28 \\
C2 & - & 3600 & 180 & 42 \\
C3 & - & 11400 & 340 & 79 \\
\hline
\end{tabular}

Note: P1 to P3 correspond to embankments planted with woody species and $\mathrm{C} 1$ to $\mathrm{C} 3$ are control sites. 
(Carrière) C.K. Schneid (cherry plum) (2.75-3 m tall and 10-12 cm diameter at breast height), surrounded by four individual, thorny, evergreen shrubs of the species $P y$ racantha coccinea $M$. Roem (firethorn) (50-60 cm tall) (Fig. 1b). We expected these structures to be attractive to birds as perches, shelter and food resources. For example, the fleshy berries of $P$. coccinea have been found in the diet of some frugivorous birds in other Mediterranean areas (Debussche, Isenmann 1994). Therefore, only individual firethorns with ripe, conspicuous, fleshy fruits over at least $30 \%$ of the shrub crown were selected. Fleshy-fruited individuals of $P$. coccinea were planted in February 2009 and those that died were replaced in October 2009. These two ornamental species were selected because they are commonly used in current revegetation practices. Neither of these two exotic, non-invasive species (Sanz-Elorza et al. 2004) was present in the surrounding vegetation, so we could assume that any propagules of these species came from our plantings.

\subsection{Bird surveys}

Bird communities and their spatial distribution within roadslopes were sampled by means of two methods. First, line transect surveys were conducted to identify species composition and to estimate bird densities at the roadsides. We surveyed each embankment on foot along its entire width in the middle of the embankment, recording all birds that were using the embankment. Since the distance from the walking line to the edge of the embankment was always less than $40 \mathrm{~m}$ (Table 1), and vegetation was mostly herbaceous, we assumed that virtually all birds were detected during censuses. Surveys were conducted between 8:00 and 13:00 h, over two consecutive years every two-three weeks from February to April 2009 and from October
2009 to March 2010 (eleven visits in total). In each census, we calculated bird species richness (number of species/ha) and density (number of individuals/ha), for both the whole set of birds and frugivorous species (birds were classified according to diet based on Cramp et al. 1977-1994; SEO BirdLife 2008). Second, the spatial distribution of birds on experimental embankments with plantings was estimated by point counts. Each embankment was surveyed for 30 minutes from a distance that was sufficiently far from the embankment to avoid interferences with birds (Verner 1985). For each bird using the embankment, we recorded the species identity and its spatial position (X, Y coordinates). We performed these counts twice per week between 8:00 and 13:00 h, randomizing the order of embankment surveys to minimize possible time effects on bird activity patterns. A total of 25 point count samples per embankment were taken from October 2009 to midMarch 2010. No survey was conducted in conditions of strong wind or rain.

\subsection{Seed dispersal by birds}

The effectiveness of birds as seed dispersers on embankments with plantings was assessed using dropping traps (Fujita, Koike 2009). We placed 32 traps (wooden frames of $50 \times 50 \mathrm{~cm}$ with a piece of tulle) on the three embankments with plantings. We placed 16 dropping traps within the planted islands (two per island in a diagonal under the cherry plum, then sampling $22 \%$ of the area of the $2.25 \mathrm{~m}^{2}$ experimental plots). The other 16 traps were placed outside the planted islands with a similar layout, halfway $(22.5 \mathrm{~m})$ between two consecutive planted islands (Fig. 1 b). Bird droppings from the traps were collected every two weeks from February 2009 to April 2009 and from October 2009 to March 2010. The seed content of

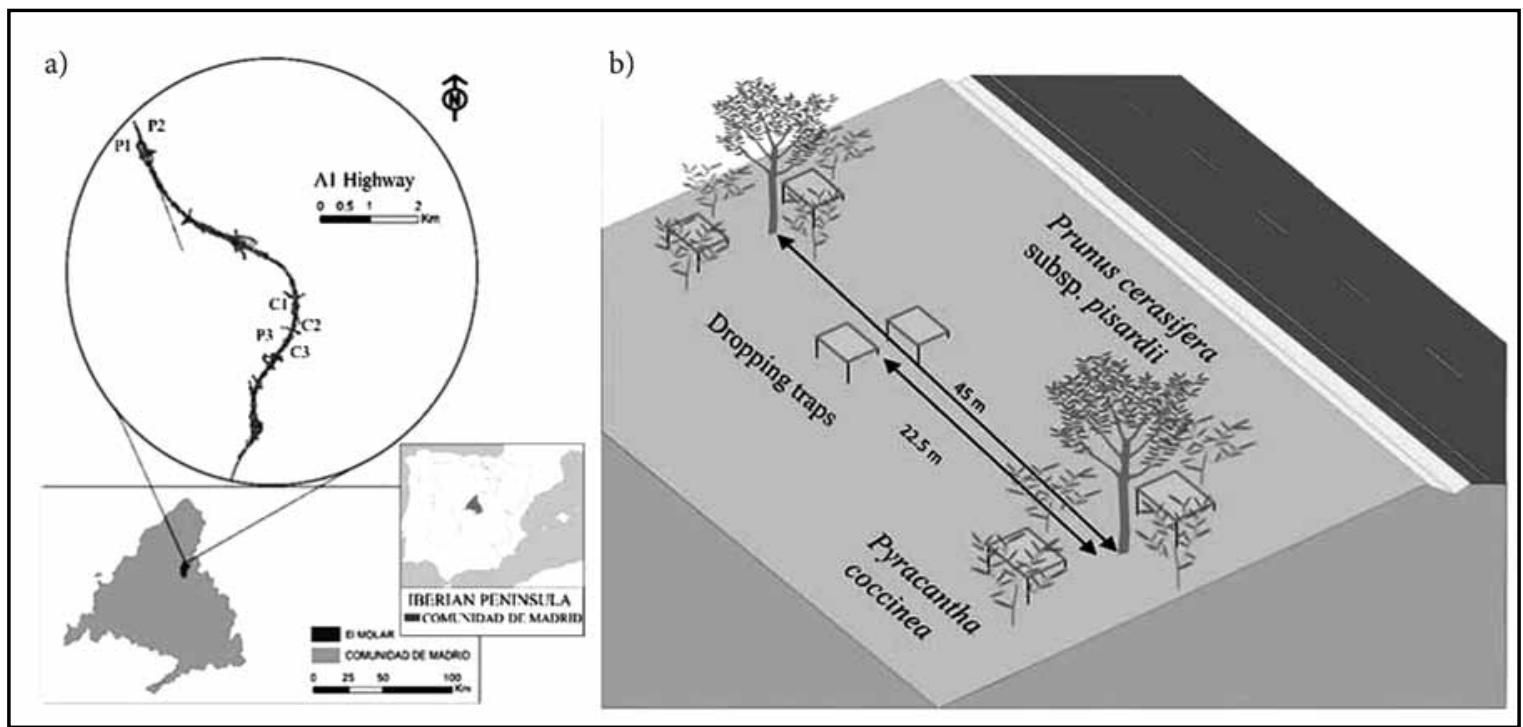

Fig. 1. Maps showing the location of the control embankments (C1 to $\mathrm{C} 3$ ) and the embankments with plantings (P1 to P3) (a). Experimental layout showing two "planted islands" and dropping traps (b) 
the droppings was examined under low power magnification (10x). All seeds were identified using an ad hoc catalogue of seeds collected from the embankments and their surrounding matrices. The viability of seeds was estimated by means of germination tests in peat at $15 \% \mathrm{RH}$ and $22{ }^{\circ} \mathrm{C}$, under a $12 \mathrm{~h} \mathrm{light}$ photoperiod for 12 months (Chamorro et al. 2013). We also measured the abundance of plants with fleshy fruits in surrounding matrices to test the effect of fruit availability on frugivorous birds. We established circular plots with a radius of $150 \mathrm{~m}$ located at the bottom and in the middle of each embankment. This distance is considered suitable for seed dispersal by smalland medium-sized birds (Jordano et al. 2007). Each circle surface was segmented into four cover layers by means of aerial photography: tree layer, shrub layer, herbaceous layer, and that occupied by infrastructures. We sampled 50 percent of the area of each of the first three layers, using one or two randomly distributed plots for the vegetation sampling. During 2009-2010 we also quantified the density of woody species providing fleshy fruits (number of individuals/ha) within the circles.

\subsection{Data analysis}

Statistical differences in richness and density of birds between the embankments with plantings and controls were analysed by means of repeated measures ANOVA. We analysed both the whole bird community and only frugivorous birds. The same analysis was used to compare the dropping rate in the traps placed inside and outside the planted islands on the embankments with plantings. In all analyses, sampling date was treated as a repeated measures factor. Bird density and the dropping rate were logarithmically transformed. We assessed Pearson correlations between the density of plants with fleshy fruits in the surrounding matrices and the density of birds (total and facultative frugivorous) on the embankments. All statistical analyses were performed with the software STATISTICA 6.0 (StatSoft, Inc. 2001).

Spatial distribution of birds was analysed by two methods. Due to the low number of observations, we examined the cumulative distribution pattern of the 25 censuses in both methods. First, differences in the occurrence of birds in plots of $4 \times 4 \mathrm{~m}$ inside and outside the planted islands were analysed using chi-square tests. Richness (number of bird species) and abundance (number of birds) inside $4 \mathrm{x} 4 \mathrm{~m}$ plots centred in the planted islands were used as the observed frequencies. To obtain the expected frequencies associated with each planted island, we randomly distributed $204 \times 4 \mathrm{~m}$ plots per island in the corresponding embankments (160 4x4 m random plots in total). We then used the average richness and abundance of each of these 20 random plots as expected frequencies associated with each island. We repeated chi-square analyses for both the whole set of species and only facultative frugivorous. Second, we used Ripley's K function to study the exact location of frugivorous birds. Point patterns of bird occurrence were analysed with the use of the pair-correlation function $g(r)$. The function $g$ is the expected density of points at a given distance divided by the intensity of the pattern, making it more suitable for pattern analyses (Stoyan, D., Stoyan H. 1994; Wiegand, Moloney 2004). We used a cell size of $1 \times 1 \mathrm{~m}$ and the ring width was one cell unit. The functions were calculated to a radius of $5 \mathrm{~m}$ and a maximum value of $r$ equal to the maximum $40 \mathrm{~m}$ (which was the maximum distance between the centre and the edge of the largest embankment). Monte Carlo simulation techniques were used to construct confidence intervals. Envelopes for the $95 \%$ confidence level were determined by the 25th-lowest and the 25th-highest value of 999 Monte Carlo simulations of heterogeneous Poisson process, alternative to the null model Complete Spatial Randomness (CSR) for point patterns in irregularly shaped areas. Under conditions of CSR, when $g(r)$ values fall between the envelopes, the spatial pattern is not significantly different from that expected by chance. When $g(r)$ values fall outside the envelopes, values $<1$ indicate regular distribution and values $>1$ indicate aggregated patterns. We performed bivariate spatial pattern analysis, which considers both the pattern of the frugivorous birds at random as well as the position of the planted islands as a pattern of fixed points on the treated embankments. Ripley's K-function analyses were performed with Programita software (Wiegand, Moloney 2004).

\section{Results}

\subsection{Seed dispersal limitation by bird availability}

A total of 3746 observations of 27 bird species on the embankments was made using both line transects and point counts (Table 2). Fringillidae was the family most commonly observed ( $76 \%$ of all observations), followed by Motacillidae (10\%) and Embericidae (7\%). The most frequently recorded bird species were linnet (Carduelis cannabina), meadow pipit (Anthus pratensis L.), goldfinch (Carduelis carduelis L.) and Eurasian chaffinch (Fringilla coelebs L.). Nearly $70 \%$ of the bird species were obligate or facultative granivorous, representing $87 \%$ of the observations. $13.4 \%$ of the observations were of species that can feed on fleshy fruits, and only 5 species were facultative frugivorous but not granivorous, accounting for just $2 \%$ of the observations (Table 2).

After controlling for embankment area, no differences were found in species richness ( $\mathrm{S}$ ) between embankments with plantings (Mean \pm S.E., $S=5.0 \pm 0.5$ species/ha per visit) and without them $(S=5.4 \pm 3.5$ species/ha per visit) (Treatment: $\mathrm{F}_{1,4}=0.05, \mathrm{p}=0.84$; Treatment $\mathrm{x}$ Date: 
$\left.\mathrm{F}_{10,40}=0.46, \mathrm{p}=0.91\right)$. Likewise, bird densities (D) were no different in embankments with (Mean \pm S.E., $\mathrm{D}=29.4 \pm$ $21.5 \mathrm{birds} / \mathrm{ha}$ per visit) and without plantings $(\mathrm{D}=47.9 \pm$ 49.9 birds/ha per visit), (Treatment: $\mathrm{F}_{1,4}=0.35, \mathrm{p}=0.59$; Treatment $x$ Date: $\left.\mathrm{F}_{10,40}=0.70, \mathrm{p}=0.72\right)$. When considering only those bird species that can feed on fleshy fruits no differences were found between embankments with plantings (Mean \pm S.E., $S=1.16 \pm 0.48$ species/ha per visit; $\mathrm{D}=$ $5.41 \pm 6.64 \mathrm{birds} / \mathrm{ha}$ per visit) and without plantings ( $\mathrm{S}=$ $1.11 \pm 1.11$ species/ha per visit; $\mathrm{D}=3.32 \pm 4.53 \mathrm{birds} / \mathrm{ha}$ per visit), either in species richness or in bird density (Repeated measures ANOVA; $p>0.05$ in both cases).

The analyses of spatial distribution of birds within embankments with plantings showed a preference for planted islands. First, chi-square analyses showed a positive selection for planted islands. The total observed species richness and abundance were 4.2 and 1.9 times higher inside than outside the islands (Richness: $\chi^{2}=136.41, \mathrm{df}=7, \mathrm{p}<$ 0.001; Abundance: $\chi^{2}=149.77, \mathrm{df}=7, \mathrm{p}<0.001$ ). Richness and abundance of facultative frugivorous species were between 8 and 4.8 times higher inside the islands (Richness: $\chi^{2}=108.75, \mathrm{df}=7, \mathrm{p}<0.001$ (Fig. $2 \mathrm{a}$ ); Abundance: $\chi^{2}=$ 681.83, df $=7, \mathrm{p}<0.001$ (Fig. 2 b)).

Second, bivariate spatial pattern analyses indicated that frugivorous birds aggregated at the planted islands (points outside of the envelopes at distances of $1 \mathrm{~m}$ in embankments P1 and P3, Fig. 3) but showed a random distribution across most of the embankment surface.

\subsection{Seed dispersal limitation by roadside resource availability}

A total of 207 droppings were collected from all traps, with higher dropping rates found in midwinter (from December $1^{\text {st }}$ to February $15^{\text {th }}$ ) with $52.2 \%$ of bird droppings (Fig. 4). There were significant differences in the dropping rate both among embankments and over time (Table 3), considering the period of arrival of wintering birds (from October to January) (Herrera 1995). Traps located inside the planted islands contained 1.7 times more feces than traps outside the islands. Embankment P3 contained between 2.4 and 2.9 times more feces than the other two embankments. Only $9 \%$ of feces contained seeds, of which $30.6 \%$ germinated. The most abundant plant species in the feces was P. coccinea (57.9\% of the seeds), followed by the herbaceous Solanum nigrum L. and Vicia dasycarpa Ten. No seeds of woody plant species from the surrounding matrix were found in the traps.

Rosa spp., Rubus ulmifolius Schott and Crataegus monogyna Jacq. were the only three species of plants with fleshy fruits found in the matrices samples. The average density of plants with fleshy fruits ranged from 12 (P1) to 93 (P3) individuals/ha. Only the density of facultative frugivorous birds was positively correlated with that
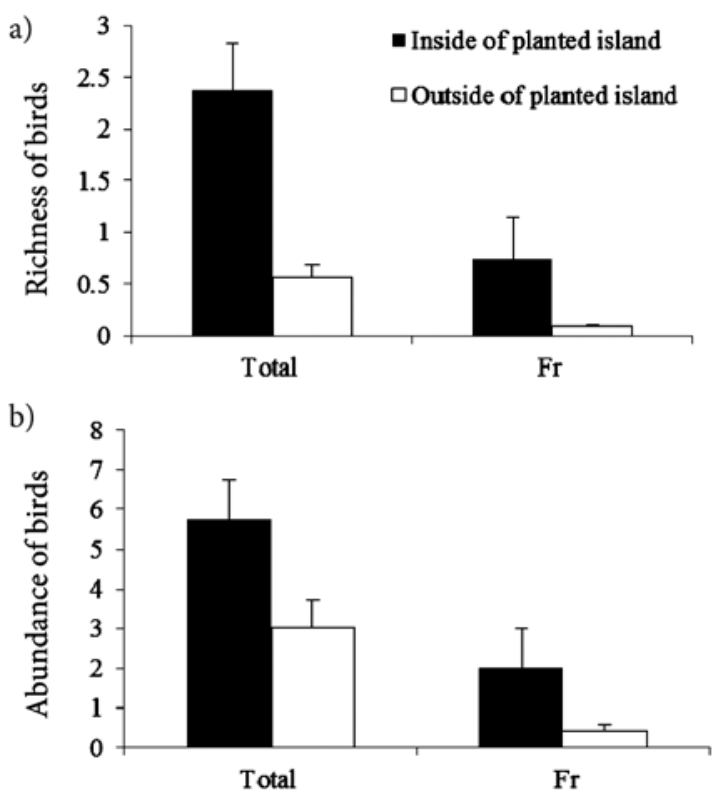

Note: Bars represent standard error.

Fig. 2. Bird species richness (a) and abundance (b) outside and inside of planted islands for all trophic groups (Total), and frugivorous birds (Fr)
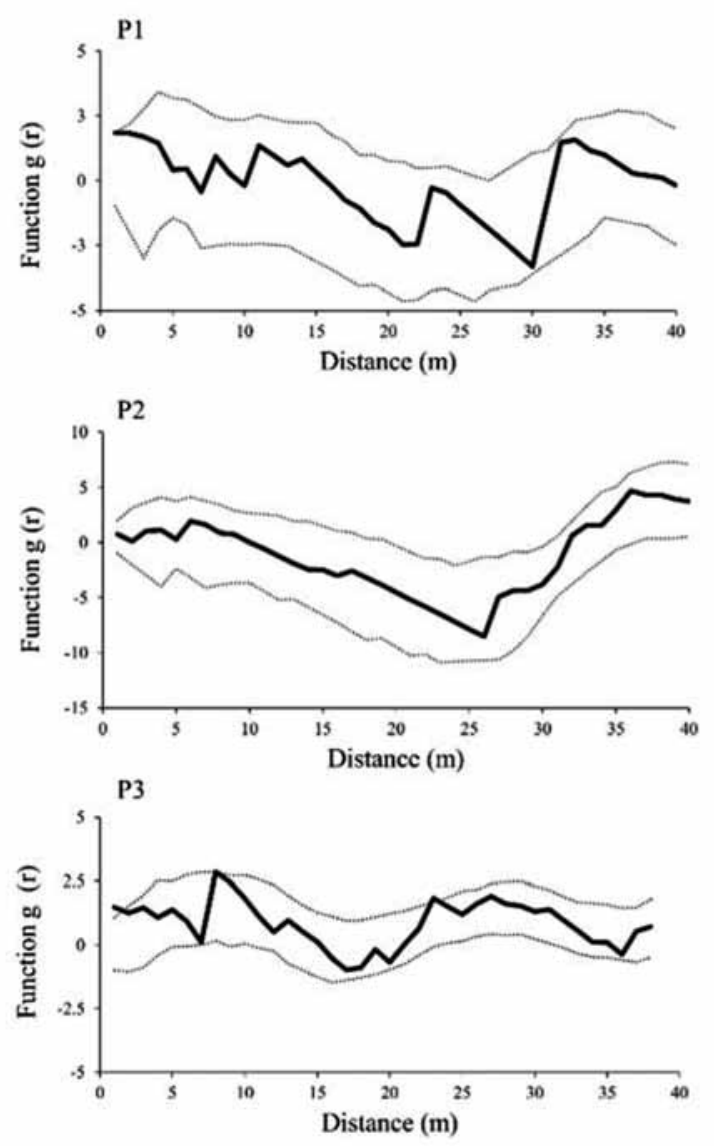

Fig. 3. Bivariate Ripley's K-function analysis of the spatial distribution of frugivorous birds at random and the position of the planted island as a pattern of fixed points for embankments with plantings (P1 to $\mathrm{P} 3$ ) 


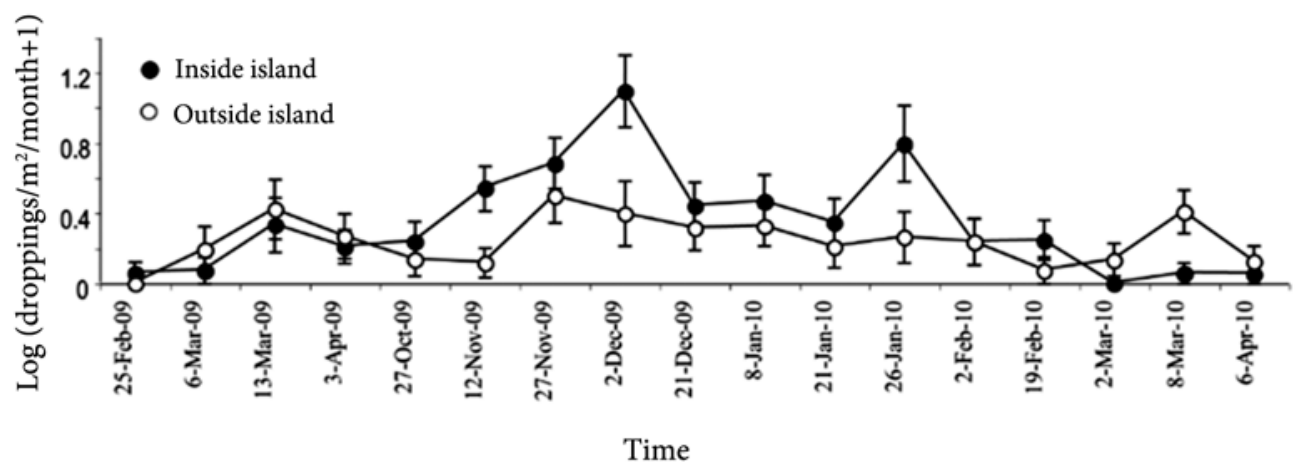

Fig. 4. Temporal variation of the dropping rate (mean $\pm \mathrm{SE}$ ) in the traps located inside and outside the planted islands

Table 2. Bird species recorded in the embankments by two sampling methods

\begin{tabular}{|c|c|c|c|c|c|c|}
\hline Scientific name & Common name & Family & $\begin{array}{l}\text { Trophic } \\
\text { group }\end{array}$ & Line transects & Point counts & $\begin{array}{c}\text { Total appearance } \\
\text { (\%) }\end{array}$ \\
\hline Alectoris rufa & Red-legged partridge & Phasianidae & Gr & 8 & 2 & 0.27 \\
\hline Anthus pratensis & Meadow pipit & Motacillidae & Gr-In & 200 & 118 & 8.49 \\
\hline Bubulcus ibis & Cattle egret & Ardeidae & In & 1 & 10 & 0.29 \\
\hline Carduelis cannabina & Linnet & Fringillidae & Gr-In & 612 & 131 & 19.83 \\
\hline Carduelis carduelis & Goldfinch & Fringillidae & $\mathrm{Gr}$ & 186 & 740 & 24.72 \\
\hline Carduelis chloris & Greenfinch & Fringillidae & Gr-In & 3 & 0 & 0.08 \\
\hline Columba palumbus & Common woodpigeon & Columbidae & Gr & 0 & 16 & 0.43 \\
\hline Emberiza cia & Rock bunting & Emberizidae & Gr-In & 10 & 4 & 0.37 \\
\hline Emberiza cirlus & Cirl bunting & Emberizidae & Gr-In & 4 & 0 & 0.11 \\
\hline Erithacus rubecula & Robin & Turdidae & In-Fr & 0 & 6 & 0.16 \\
\hline Fringilla coelebs & Eurasian Chaffinch & Fringillidae & Gr-In-Fr & 121 & 234 & 9.48 \\
\hline Galerida cristata & Crested lark & Alaudidae & Gr-In & 25 & 19 & 1.17 \\
\hline Lanius meridionalis & Woodchat shrike & Laniidae & In-Ca & 0 & 1 & 0.03 \\
\hline Miliaria calandra & Corn bunting & Emberizidae & Gr-In & 93 & 138 & 6.17 \\
\hline Motacilla alba & White wagtail & Motacillidae & In & 20 & 31 & 1.36 \\
\hline Parus caeruleus & Blue tit & Paridae & Gr-In-Fr & 0 & 1 & 0.03 \\
\hline Parus major & Great tit & Paridae & In-Fr & 0 & 4 & 0.11 \\
\hline Passer domesticus & House sparrow & Passeridae & $\mathrm{Om}$ & 13 & 5 & 0.48 \\
\hline Passer montanus & Eurasian tree sparrow & Passeridae & Om & 4 & 0 & 0.11 \\
\hline Phoenicurus ochruros & Black redstart & Turdidae & Gr-In-Fr & 3 & 28 & 0.83 \\
\hline Phylloscopus collybita & Common chiffchaff & Sylviidae & In-Fr & 9 & 54 & 1.68 \\
\hline Pica pica & Common magpie & Corvidae & $\mathrm{Om}$ & 11 & 8 & 0.51 \\
\hline Saxicola torquata & Common stonechat & Turdidae & Gr-In-Fr & 13 & 26 & 1.04 \\
\hline Serinus serinus & Serin & Fringillidae & Gr-In & 129 & 83 & 5.66 \\
\hline Sturnus unicolor & Spotless starling & Sturnidae & Gr-In-Fr & 0 & 1 & 0.03 \\
\hline Sylvia atricapilla & Blackcap & Sylviidae & In-Fr & 0 & 2 & 0.05 \\
\hline Sylvia melanocephala & Sardinian warbler & Sylviidae & In-Fr & 0 & 1 & 0.03 \\
\hline Troglodytes troglodytes & Winter wren & Troglodytidae & In & 1 & 0 & 0.03 \\
\hline Not identified & - & Fringilidae & - & 0 & 610 & 16.28 \\
\hline Not identified & - & - & - & 0 & 7 & 0.19 \\
\hline
\end{tabular}

Note: line transects $(\mathrm{n}=1466$ observations) and point counts $(\mathrm{n}=2280)$. The trophic group is indicated for each species: granivorous (Gr), insectivorous (In), frugivorous (Fr), carnivores (Ca) and omnivores (Om) according to Cramp et al. 1977-1994; SEO BirdLife 2008. The number of individuals detected per species is shown for each sampling method. The percentage of bird appearance was calculated across the two sampling methods. 
of woody plants with fleshy fruits $(\mathrm{r}=0.976, \mathrm{p}<0.001$, $\mathrm{n}=6$ ). Embankment P3 presented the highest density of both facultative frugivorous birds and plants with fleshy fruits in its immediate vicinity. On the contrary, embankment P1 had the lowest values for both variables.

Table 3. Repeated measures ANOVAs considering the effect of site (embankment) and trap location (inside/outside island) on dropping rate with time as repeated factor

\begin{tabular}{|c|c|c|c|c|c|c|}
\hline & \multicolumn{3}{|c|}{ February 09-April 10} & \multicolumn{3}{|c|}{ October 09-January 10} \\
\hline & $\mathrm{df}$ & $\mathrm{F}$ & $\mathrm{p}$ & $\mathrm{df}$ & $\mathrm{F}$ & $\mathrm{p}$ \\
\hline Embankment & 2 & 5.95 & 0.007 & 2 & 13.57 & $<0.001$ \\
\hline $\begin{array}{l}\text { Inside/Out- } \\
\text { side island }\end{array}$ & 1 & 3.78 & 0.063 & 1 & 3.65 & 0.04 \\
\hline $\begin{array}{l}\text { Embankment } \\
\mathrm{x} \text { Inside/Out- } \\
\text { side island }\end{array}$ & 2 & 0.09 & 0.913 & 2 & 0.14 & 0.871 \\
\hline Time & 16 & 5.91 & $<0.001$ & 7 & 3.51 & $<0.001$ \\
\hline $\begin{array}{l}\text { Time x Em- } \\
\text { bankment }\end{array}$ & 32 & 2.85 & $<0.001$ & 14 & 1.84 & 0.036 \\
\hline $\begin{array}{l}\text { Time } \mathrm{x} \\
\text { Inside/Out- } \\
\text { side island } \\
\end{array}$ & 16 & 2.63 & $<0.001$ & 7 & 1.43 & 0.195 \\
\hline $\begin{array}{l}\text { Time x Em- } \\
\text { bankment } x \\
\text { Inside/Out- } \\
\text { side island }\end{array}$ & 32 & 1.76 & 0.007 & 14 & 2.15 & 0.011 \\
\hline
\end{tabular}

Note: the analysis was performed over the whole sampling period (17 surveys: from February 2009 to April 2010) and the most active period for birds (8 surveys: from October 2009 to January 2010; see also Fig. 4).

\section{Discussion}

In ecological restoration, local actions such as plantings, are expected to deliver outcomes at larger scales, for instance, development of dispersal linkages (see for instance Wydhayagarn et al. 2009; Rey Benayas et al. 2008). However, most restoration actions in roadslopes are designed either for ornamental purposes, increasing safety or reducing slope instability, without taking into account their potential effect to restore ecological processes. Our results show that plantings designed specifically as bird attractors implemented in roadside revegetation are successful in attracting bird but fail to consistently foster bird-mediated seed dispersal from the agricultural and peri-urban surrounding matrices. This failure is not due to a low bird density at the roadside but rather to an avian community shaped by the history and structure of the surrounding landscape.

\subsection{Seed dispersal limitation by bird availability}

Despite being a human-altered habitat, we find high bird densities in the embankments. High abundances in agricultural landscapes are often found in strip-cover habitats such as railways or roadsides in winter (Best et al. 1995; Delgado, Moreira 2000). During this season, many bird species aggregate in flocks due to less selective habitat use or higher avian sociality (Morse 1982; Wiens 1989). The roadsides mainly include grasses and other herbaceous species, which are not usually mowed in winter. Granivorous birds may find suitable habitats in the roadsides during winter, when the availability of food (seeds, insects, plants, etc.) and shelter is very low in most agricultural stands in the surrounding area. However, these high densities in roadsides are paralleled by relatively low species richness, which is consistent with previous reports on road effects on bird community composition through habitat loss (Laurance 2004), traffic noise disturbance (Bautista et al. 2004), predation (Bergin et al. 2000), or collisions with vehicles (Erickson et al. 2005). Nevertheless, for our case, the dominance of granivorous can better explain the high density of birds but the low richness of species.

The avian community of the study embankments is dominated by granivorous species, in consonance with the surrounding agricultural landscape. Granivorous species sporadically use planted stands of woody plants, apart from not being efficient seed dispersers. Thus, the exozoochorous contribution of this type of birds appears to be bound to particular environmental conditions (Twigg et al. 2009). Conversely, the low abundance of frugivorous birds find in the embankments is not related to bird density, which was ten times higher if considering all birds present at the roadside than what had been reported for the surrounding area (Carrascal et al. 2002) and for similar scenarios (Díaz, Tellería 1994). Considering that the abundance of frugivorous birds is a good predictor for seed dispersal capacity in human-altered landscapes (García et al. 2010), the low number of frugivorous birds found in our study severely hampers the potential seed dispersal.

\subsection{Seed dispersal limitation by roadside resource availability}

Woody islands act as selective attractors for birds and several frugivorous species use the planted stands as food resources and perches. Consumption of fleshy fruits is evidenced by the presence of viable seeds from the planted $P$. coccinea shrubs in bird feces. The highest values of bird droppings were found between October and January, when the influx of winter migrants in the Mediterranean region is higher (Herrera 1995). These findings support the potential role of plantings in activating or facilitating ecological processes such as seed dispersal. In fact, persistence or establishment of islands of woody vegetation in extensive agricultural landscapes has often 
been recommended with regard to fostering biota restoration to respond to land use changes (Rey Benayas et al. 2008; Herrera, García 2009; Manning et al. 2009). Furthermore, previous reports have suggested that bird perching may even offset frugivorous bird scarcity in human-altered environments (Herrera, García 2009). Recent studies revealed that in agricultural landscapes, isolated trees are able to disperse to nearby roadside environments via frugivore activity (Coulson et al. 2014). In the present study, the attraction of frugivorous birds by plantings was highly skewed among roadslopes. This site (embankment) dependency is linked to the high correlation observed between the density of frugivorous birds at the roadside and the density of fleshy-fruited plants in the surrounding matrix. Nevertheless, these results should be regarded with caution due to the small sample size. More years of monitoring may be required due to the time needed by birds to gather new resources.

We surmise that a mismatch between the local revegetation actions and the landscape structure of the matrix may explain why the seeds from the fleshy-fruited species (Rosa spp., Rubus ulmifolius, or Crataegus monogyna) in the adjacent matrices never reached the planted stands. In practical terms, the connection of the planted stands would have required restoration action in the surrounding matrix, such as the establishment of stepping-stone corridors (sensu Gillies, St. Clair 2010), through planting of clumps of fleshyfruited shrubs to channel movements of seed-dispersing birds. In summary, current landscape heterogeneity provides the structural frame into which disturbed sites, such as roadslopes, should be 'plugged' in order to restore ecological connectivity within the ecosystem mosaic.

\section{Conclusions}

1. Plantings of ornamental woody species with fleshy fruits acted as selective attractors for frugivorous birds on embankments. These experimental woody islands provided perches and food to some bird species. These results suggest that revegetation practices can be designed to restore ecological processes, not just for slope stability and ornamental purposes.

2. Effective seed dispersal by birds was not detected probably because the low abundance of frugivorous birds (the bird community in the area was dominated by granivorous species, as a result of a long history of urbanization and agricultural land use).

3. Local revegetation practices must consider the surrounding landscape. The lack of awareness of the surrounding landscape structure may jeopardize the success of ecological restoration actions at the roadside.

4. Our findings support top-down approaches to design restoration actions that first consider broad-scale drivers and then restoration protocols and local actions.

\section{Acknowledgments}

Sadly, our dear colleague and friend Luis Balaguer passed away on the 19th of March 2014. This publication is dedicated in grateful tribute to him. We are indebted to Manuel Villén and Luís García-Linares at the R and D Department of Obrascon Huarte Lain, S.A. (OHL) for their support, permission to publish this paper and, in particular, for their commitment to the environmental integration of transport infrastructures. We thank Ana Vázquez Benítez and Silvia Murillo Burgaña for their assistance in the laboratory and field work. This research was funded by the Spanish Ministry of Economy and Competitiveness (ECONECT project: CDTI IDI-20120317). We also wish to thank the Regional Government of Madrid for financial support through the network REMEDINAL3-CM (S2013/MAE-271).

\section{References}

Bautista, L. M.; García, J. T.; Calmaestra, R. G.; Palacín, C.; Martín, C. A.; Morales, M. B.; Bonal, R.; Viñuela, J. 2004. Effect of weekend road traffic on the use of space by raptors, Conservation Biology 18: 726-732.

http://dx.doi.org/10.1111/j.1523-1739.2004.00499.x

Bengtsson, J.; Angelstam, P.; Elmqvist, T.; Emanuelsson, U.; Folke, C.; Ihse, M.; Moberg, F.; Nyström, M. 2003. Reserves, resilience and dynamic landscapes, Ambio 32: 389-396. http://dx.doi.org/10.1579/0044-7447-32.6.389

Bergin, T. M.; Best, L. B.; Freemark, K. E.; Koehler, K. J. 2000. Effects of landscape structure on nest predation in roadsides of a midwestern agroecosystem: a multiscale analysis, Landscape Ecology 15: 131-143.

Best, L. B.; Freemark, K. E.; Dinsmore, J. J.; Camp, M. 1995. A review and synthesis of habitat use by breeding birds in agricultural landscapes of Iowa, American Midland Naturalist 134: 1-29. http://dx.doi.org/10.2307/2426479

Bochet, E.; García-Fayos, P.; Tormo, J. 2007. Road slope revegetation in semiarid Mediterranean environments. Part I: Seed dispersal and spontaneous colonization, Restoration Ecology 15: 88-96.

http://dx.doi.org/10.1111/j.1526-100X.2006.00193.x

Bonet, A. 2004. Secondary succession of semi-arid Mediterranean old-fields in south-eastern Spain: insights for conservation and restoration of degraded lands, Journal of Arid Environments 56: 213-233. http://dx.doi.org/10.1016/S0140-1963(03)00048-X

Carrascal, L. M.; Palomino, D.; Lobo, J. M. 2002. Patrones de preferencias de hábitat y de distribución y abundancia invernal de aves en el centro de España. Análisis y predicción del efecto de factores ecológicos, Animal Biodiversity and Conservation 1: 7-40 (in Spanish).

Chamorro, D.; Luna, B.; Moreno, J. M. 2013. Germination response to various temperature regimes of four Mediterranean seeder shrubs across a range of altitudes, Plant ecology 214(12): 1431-1441. http://dx.doi.org/10.1007/s11258-013-0264-0

Clevenger, A. P.; Chruszcz, B.; Gunson, K. E. 2003. Spatial patterns and factors influencing small vertebrate fauna road-kill aggregations, Biology Conservation 109: 15-26. http://dx.doi.org/10.1016/S0006-3207(02)00127-1 
Coffin, A. W. 2007. From roadkill to road ecology: a review of the ecological effects of roads, Journal of Transport Geography 15(5) : 396-406. http://dx.doi.org/10.1016/j.jtrangeo.2006.11.006

Coulson, C.; Spooner, P. G.; Lunt, I. D.; Watson, S. J. 2014. From the matrix to roadsides and beyond: the role of isolated paddock trees as dispersal points for invasion, Diversity and Distribution 20: 137-148. http://dx.doi.org/10.1111/ddi.12135

Cramp, S.; Simmons, K. E. L.; Perrins, C. 1977-1994. Handbook of the Birds of Europe, the Middle East and North Africa. 9 Volumes. Oxford: Oxford University Press.

de la Riva, E. G.; Casado, M. A.; Jiménez, M. D.; Mola, I.; Costa-Tenorio, M.; Balaguer, L. 2011. Rates of local colonization and extinction reveal different plant community assembly mechanisms on road verges in central Spain, Journal of Vegetation Science 22: 292-302. http://dx.doi.org/10.1111/j.1654-1103.2010.01248.x

Debussche, M.; Isenmann, P. 1994. Bird-dispersed seed rain and seedling establishment in patchy Mediterranean vegetation, Oikos 69: 414-426. http://dx.doi.org/10.2307/3545854

Delgado, A.; Moreira, F. 2000. Bird assemblages of an Iberian cereal steppe, Agriculture, Ecosystems and Environment 78: 65-76. http://dx.doi.org/10.1016/S0167-8809(99)00114-0

Díaz, M.; Tellería, J. 1994. Predicting the effects of agricultural changes in central Spanish croplands on seed-eating overwintering birds, Agriculture, Ecosystems and Environment 49: 289-298. http://dx.doi.org/10.1016/0167-8809(94)90058-2

Erickson, W. P.; Johnson, G. D.; Young Jr., D. P. 2005. A summary and comparison of bird mortality from anthropogenic causes with an emphasis on collisions, US Forest Service General Technical Report, PSW 191: 1029-1042. http://dx.doi.org/10.1111/j.0022-0477.2004.00882.x

Fujita, M.; Koike, F. 2009. Landscape effects on ecosystems: birds as active vectors of nutrient transport to fragmented urban forests versus forest-dominated landscapes, Ecosystems 12: 391-400. http://dx.doi.org/10.1007/s10021-009-9230-z

García, D.; Zamora, R.; Amico, G. C. 2010. Birds as suppliers of seed dispersal in temperate ecosystems: conservation guidelines from real-world landscapes, Conservation Biology 24: 1070-1079. http://dx.doi.org/10.1111/j.1523-1739.2009.01440.x

Gillies, C. S.; St. Clair, C. C. 2010. Functional responses in habitat selection by tropical birds moving through fragmented forest, Journal Applied Ecology 47: 182-190.

http://dx.doi.org/10.1111/j.1365-2664.2009.01756.x

Herrera, C. M. 1995. Plant-vertebrate seed dispersal systems in the mediterranean: ecological, evolutionary, and historical determinants, Annual Review of Ecology and Systematics 26: 705-727. http://dx.doi.org/10.1146/annurev.ecolsys.26.1.705

Herrera, J. M.; García, D. 2009. The role of remnant trees in seed dispersal through the matrix: being alone is not always so sad, Biological Conservation 142: 149-158. http://dx.doi.org/10.1016/j.biocon.2008.10.008

Holl, K. D.; Loik, M. E.; Lin, E. H. V.; Samuels, I. A. 2000. Tropical montane forest restoration in Costa Rica: overcoming barriers to dispersal and establishment, Restoration Ecology 8: 339-349. http://dx.doi.org/10.1046/j.1526-100x.2000.80049.x

Howe, H. F.; Miriti, M. N. 2004. When seed dispersal matters, Bioscience 54: 651-660. http://dx.doi.org/10.1641/00063568(2004)054\%5B0651:WSDM\%5D2.0.CO;2
Howe, H. F.; Smallwood, J. 1982. Ecology of seed dispersal, Annual Review of Ecology and Systematics 13: 201-228. http://dx.doi.org/10.1146/annurev.es.13.110182.001221

Huijser, M. P.; Clevenger A. P. 2006. Habitat and corridor function of rights-of-way, in J. Davenport, J. L. Davenport (Eds.). The ecology of transportation: managing mobility for the environment. London: Springer, 233-254. http://dx.doi.org/10.1007/1-4020-4504-2_11

Jordano, P.; García, C.; Godoy, J. A.; García-Castaño, J. L. 2007. Differential contribution of frugivores to complex seed dispersal patterns, Proceedings of the National Academy of Sciences USA 104: 3278-3282. http://dx.doi.org/10.1073/pnas.0606793104

Kociolek, A. V.; Clevenger, A. P.; St Clair, C. C.; Proppe, D. S. 2011. Effects of road networks on bird populations, Conservation Biology 25: 241-249. http://dx.doi.org/10.1111/j.1523-1739.2010.01635.x

Lambertucci, S. A.; Speziale, K. L.; Rogers, T. E.; Morales, J. M. 2009. How do roads affect the habitat use of an assemblage of scavenging raptors?, Biodiversity Conservation 18: 20632074. http://dx.doi.org/10.1007/s10531-008-9573-3

Laurance, S. G. W. 2004. Responses of understory rain forest birds to road edges in Central Amazonia, Ecological Applications 14: 1344-1357. http://dx.doi.org/10.1890/03-5194

Ludwig, A. J.; Tongway, D. J.; Freudenberger, D.; Noble, J.; Hodgkinson, K. (Eds.). 1997. Landscape ecology, function and management: principles from Australia's rangelands. Melbourne: CSIRO Publishing.

Manning, A. D.; Gibbons, P.; Lindenmayer, D. B. 2009. Scattered trees: a complementary strategy for facilitating adaptive responses to climate change in modified landscapes?, Journal Applied Ecology 46: 915-919. http://dx.doi.org/10.1111/j.1365-2664.2009.01657.x

Méndez, M.; García, D.; Maestre, F. T.; Escudero, A. 2008. More ecology is needed to restore mediterranean ecosystems: a reply to Valladares and Gianoli, Restoration Ecology 16: 210216. http://dx.doi.org/10.1111/j.1526-100X.2008.00390.x

Meunier, F.; Verheyden, C.; Jouventin, P. 1999. Bird communities of highway verges: influence of adjacent habitat and roadside management, Acta Oecologica 20: 1-13. http://dx.doi.org/10.1016/S1146-609X(99)80010-1

Mola, I.; Jiménez, M. D.; López-Jiménez, N.; Casado, M. A.; Balaguer, L. 2011. Roadside reclamation outside the revegetation season: management options under schedule pressure, Restoration Ecology 19: 83-92. http://dx.doi.org/10.1111/j.1526-100X.2009.00547.x

Morse, D. H. 1982. Behavioral mechanisms in ecology. Cambridge: Harvard University Press.

Nathan, R.; Schurr, F. M.; Spiegel, O.; Steinitz, O.; Trakhtenbrot, A.; Tsoar, A. 2008. Mechanisms of long-distance seed dispersal, Trends in Ecology and Evolution 23: 638-647. http://dx.doi.org/10.1016/j.tree.2008.08.003

Reijnen, R.; Foppen, R. 2006. Impact of road traffic on breeding bird populations, in J. Davenport, J. L. Davenport (Eds.). The ecology of transportation: managing mobility for the environment. London: Springer, 255-274. http://dx.doi.org/10.1007/1-4020-4504-2_12

Rey Benayas, J. M.; Bullock, J. M.; Newton, A. C. 2008. Creating woodland islets to reconcile ecological restoration, conservation, and agricultural land use, Frontiers in Ecology and the Environment 6: 329-336. http://dx.doi.org/10.1890/070057 
Sanz-Elorza, M.; Dana, E. D.; Sobrino, E. 2004. Atlas de las plantas alóctonas invasoras en España. Madrid: Ministerio de Medio Ambiente, Organismo Autónomo Parque Nacionales (in Spanish).

Sekercioglu, C. H. 2006. Increasing awareness of avian ecological function, Trends Ecology and Evolution 21: 464-471. http://dx.doi.org/10.1016/j.tree.2006.05.007

SEO BirdLife. 2008. La enciclopedia de las aves de España [on line], [cited 16 October 2014] (in Spanish). Available from Internet: http://www.enciclopediadelasaves.es/originales/Enciclopedia_Aves.htm

StatSoft Inc. 2001. Statistica for Windows 6.0. Tulsa, Oklahoma: Statsoft Inc.

Stoyan, D.; Stoyan, H. 1994. Fractal, random shapes and point field. Chichester: Wiley, 389.

Tormo, J.; Bochet, E.; García-Fayos, P. 2007. Roadfill revegetation in semiarid Mediterranean environments. Part II: topsoiling, species selection, and hydroseeding, Restoration Ecology 15: 97-102. http://dx.doi.org/10.1111/j.1526-100X.2006.00194.x

Twigg, L. E.; Lowe, T. J.; Taylor, C. M.; Calver, M. C.; Martin, G. R.; Stevenson, C.; How, R. 2009. The potential of seed-eating birds to spread viable seeds of weeds and other undesirable plants, Austral Ecology 34: 805-820. http://dx.doi.org/10.1111/j.1442-9993.2009.01992.x

Verner, J. 1985. Assessment on counting techniques, in R. F. Johnson (Ed.). Current ornithology. Vol. 2. New York: Plenum Press, 247-302.

Wiegand, T.; Moloney, K. A. 2004. Rings, circles, and null-models for point pattern analysis in ecology, Oikos 104: 209-229. http://dx.doi.org/10.1111/j.0030-1299.2004.12497.x

Wiens, J. A. 1989. Spatial scaling in ecology, Functional Ecology 3: 385-397.

Wydhayagarn, C.; Elliott, S.; Wangpakapattanawong, P. 2009. Bird communities and seedling recruitment in restoring seasonally dry forest using the framework species method in Northern Thailand, New Forests 38: 81-97. http://dx.doi.org/10.1007/s11056-009-9133-z

Wilkinson, D. M. 1997. Plant colonization: are wind dispersed seeds really dispersed by birds at large spatial and temporal scales?, Journal of Biogeography 24: 61-65. http://dx.doi.org/10.1111/j.1365-2699.1997.tb00050.x

Zamora, R.; Hódar, J. A.; Matías, L.; Mendoza, I. 2010. Positive adjacency effects mediated by seed disperser birds in pine plantations, Ecological Applications 20: 1053-60. http://dx.doi.org/10.1890/09-0055.1

Rocío de TORRE. Doctor of Ecology, Conservation and Restoration of Ecosystems of the University of Alcalá, Spain, 2014. Author of 2 scientific papers under review. Scientific interests: plant ecology and plant-animal and plant-environment interactions, across different levels of organisation as individuals, communities, ecosystems and landscapes.

María Dolores JIMÉNEZ. Assistant Professor of Ecology at the Complutense University, Madrid, Spain. Doctor of Biology of the Politécnica University, Madrid, Spain, 2007. Author of 18 scientific papers. Scientific interests: urban ecology, forest ecology and restoration ecology, in order to take into account the anthropogenic factor on ecosystem and communities functioning.

Álvaro RAMÍREZ. Lecturer at the Department of Zoology and Physical Anthropology, at the Complutense University, Madrid, Spain. Doctor of Biology of the Complutense University, Madrid, Spain, 2004. Author of 14 scientific papers. Scientific interests: animal ecology, biogeography and conservation biology, using birds as a study model.

Ignacio MOLA. Technical Advisor of the Research, Development and Innovation (R\&D) Service of the Construction Company OHL (Obrascón Huarte Laín S. A.), Madrid, Spain. Bachelor in Biology from Autónoma University, Madrid, Spain, 2002. Author of 6 scientific papers and co-editor of one book (co-author of 4 chapters). Scientific interests: factors which are driving the vegetation establishments at the roadside under Mediterranean conditions.

Miguel A. CASADO. Associate Professor of Ecology at the Complutense University, Madrid, Spain. Doctor of Biology of Autónoma University, Madrid, Spain, 1987. Author of 65 scientific publications, co-editor of 4 books and 24 book chapters. Scientific interests: ecology of agrosilvopastoral systems, as well as restoration ecology.

Luis BALAGUER. Associate Professor of Plant Biology at the University Complutense, Madrid, Spain. Unfortunately, our dear friend and colleague Luis Balaguer passed away on March 19 $9^{\text {th }}, 2014$. He published 48 scientific papers and several book chapters. His research and teaching interest was focussed on restoration ecology and evolutionary ecology from a holistic point of view. 